\title{
Responses of the Squash Bug (Hemiptera: Coreidae) and Its Egg Parasitoid, Gryon pennsylvanicum (Hymenoptera: Scelionidae) to Three Cucurbita Cultivars
}

\author{
ELIZABETH A. VOGT AND JAMES R. NECHOLS \\ Department of Entomology, Kansas State University, Manhattan, KS 66506
}

\begin{abstract}
Environ. Entomol. 22(1): 238-245 (1993)
ABSTRACT Laboratory experiments were conducted to quantify effects of resistant and susceptible host plants on the preimaginal and adult biologies of the squash bug, Anaso tristis (De Geer), and its egg parasitoid, Gryon pennsylvanicum (Ashmead). 'Early Prolific Straightneck' squash, 'Green Striped Cushaw' pumpkin, and 'Waltham Butternut' squash served as test plants. Preimaginal development of the squash bug (egg to adult) was similar on all three cultivars (range: $31-35 \mathrm{~d}$ ). However, survivorship to the adult was significantly lower on 'Green Striped Cushaw' and 'Waltham Butternut' than on 'Early Prolific Straightneck'. Statistical differences in survivorship were not observed in second-generation squash bugs, suggesting that some selection may have occurred. Squash bug reproduction and longevity were similar on all three cultivars. However, the reduced juvenile survivorship on 'Green Striped Cushaw' and 'Waltham Butternut' resulted in significantly lower $r_{\max }$ values on these cultivars than on the more susceptible 'Early Prolific Straightneck'. The dietary history of adult squash bugs did not significantly affect development, preimaginal survival, or reproduction of $G$. pennsylvanicum. However, adult longevity of the parasitoid was significantly reduced when its larvae developed in eggs of squash bugs that were reared on the most resistant cultivar ('Waltham Butternut').
\end{abstract}

KEY WORDS tri-trophic interactions, biological control, host plant resistance

PLANTS THAT EXHIBIT resistance to arthropod pests may have a variety of adverse effects on natural enemy species (e.g., see Bergman \& Tingey 1979, Price et al. 1980, Boethel \& Eikenbary 1986, Obrycki 1986). Some of the most commonly reported deleterious effects are those that result from natural enemies feeding directly on host or prey individuals that have ingested plant toxins (Thurston \& Fox 1972; Campbell \& Duffey 1979; Kauffman \& Kennedy 1989 a,b). However, recent studies involving egg parasitoids indicate that factors associated with resistant host plants may be transferred indirectly to parasitoids from adult insect hosts via their eggs (Orr et al. 1985, Ruberson et al. 1989).

Indirect effects on host egg quality may have an important bearing on the successful development of a biological control program for the squash bug, Anasa tristis (De Geer), because most of its naturally occurring enemies are egg parasitoids (Nechols 1985; Tracy \& Nechols 1987, 1988; Nechols et al. 1989). In addition, several cultivars of squash and pumpkins are known to possess various levels of resistance to the squash bug (Novero et al. 1962, Benepal \& Hall 1967). These cultivars could be planted and used directly or serve as germplasm for a breed- ing program to develop squash bug-resistant varieties.

The scelionid egg parasitoid Gryon pennsylvanicum (Ashmead) has a number of attributes that make it a potentially good candidate for mass rearing and augmentative release against the squash bug (Nechols et al. 1989). However, its interaction with resistant cultivars has not been investigated. Furthermore, no quantitative study has been made of the effects of resistant cultivars on the squash bug. Therefore, the objective of our study was to quantify the effects of selected cucurbit cultivars on the development, survival, longevity, and reproductive biology of both the squash bug and $G$. pennsylvanicum.

\section{Materials and Methods}

Plant and Insect Cultures. All plants were grown in a greenhouse supplemented with artificial light (fluorescent 50:50 mixture of Cool White:Grow Lux lamps). The photoperiod was 16:8 (L:D) h.

Squash bug colonies originated from eggs, nymphs, and adults that were collected from squash and pumpkin fields near Manhattan, KS, in July 1987 (for the 1988 experiments) and July 1988 (for the 1989 experiments). Colonies were 
maintained in a rearing room in large, meshcovered, frame cages under a photoperiod of 16:8 (L:D) h at $27 \pm 1^{\circ} \mathrm{C}$ on 7 to 9 -wk-old potted plants of our standard cultivar 'Early Prolific Straightneck' squash (Cucurbita pepo L.) (Wilhitte Seed, Poolville, TX). Relative humidity was $65-75 \%$, and illumination was provided by fluorescent lamps as described above.

Parasitoid colonies were initiated in August 1987 and 1988 by collecting adult G. pennsylvanicum and parasitized squash bug egg masses from the same field locations as those used to collect squash bugs. Adult parasitoids were fed honey and free water in Plexiglas colony boxes that maintained $\approx 75 \% \mathrm{RH}$, in growth chambers at $26.2 \pm 0.5^{\circ} \mathrm{C}$ under a photoperiod of $16: 8(\mathrm{~L}: \mathrm{D})$ h. On alternate days, paper strips containing 1-dold squash bug egg masses were provided. To obtain newly emerged adult parasitoids for experiments, several parasitized egg masses were collected from colonies and transferred to glass shell vials several days before expected parasitoid emergence and checked twice daily.

Voucher specimens of the squash bug and $G$. pennsylvanicum have been deposited under Lot Number 036 in the entomology research collection at Kansas State University, Manhattan, KS.

Preimaginal Development, Survivorship, Sex Ratio, and Adult Weights of Squash Bugs. Two experiments were run to determine squash bug preimaginal developmental times, stage-specific survivorship, adult sex ratio, and adult weights on different cucurbit hosts. In 1988, the experiment was run for one generation; in 1989, it spanned two generations. In the one-generation experiment, squash bug eggs were obtained from females that had been reared on 'Early Prolific Straightneck'. Percentage egg hatch and time to egg hatch were obtained by placing 90 newly laid (<1-d-old) squash bug eggs ( $\approx$ five egg masses) in a petri dish ( 100 by $15 \mathrm{~mm}$ ), which then was placed in a humidity box within a growth chamber set at $26.2 \pm 0.5^{\circ} \mathrm{C}, 16: 8(\mathrm{~L}: \mathrm{D}) \mathrm{h}$ and $\approx 75 \% \mathrm{RH}$. Nine dishes were set up and checked twice daily for squash bug hatch. Eighty newly eclosed first instars then were chosen from each dish and placed on the upper leaf surface of one-mo-old potted plants of each of the three cultivars: 'Early Prolific Straighneck' (described above), 'Green Striped Cushaw' pumpkin (C. maxima Duch.), and 'Waltham Butternut' squash (C. moshata Duch.). We chose these cultivars because Novero et al. (1962) indicated that they represented different levels of resistance to the squash bug. Three screened, frame cages ( $\approx 45$ by 22 by $35 \mathrm{~cm}$ ), each containing two plants of the same cultivar (one of which was infested with squash bugs), were placed in a growth chamber under conditions described above. Three chambers were used simultaneously over three consecutive test periods (i.e., blocks) for a total of nine cages (i.e., replicates) per cultivar.
Each day, the number of living and dead nymphs in each stadium were recorded and exuviae were removed. When bugs reached the adult stage, their sex was determined. Plants were bottomwatered on alternate days and replaced every fifth or sixth day as needed.

In the two-generation study, procedures were the same as those described above except that only two cultivars ('Early Prolific Straightneck' and 'Waltham Butternut') were used. In these tests, four cages-two for each cultivar-were placed in a random arrangement within each of the two growth chambers for a total of four replicates. The second generation was then initiated with squash bug eggs that were collected randomly from first-generation females reared on the two different cultivars. Adult squash bug weights were recorded within $15 \mathrm{~h}$ of eclosion.

The GLM-LS means test ( $P \leq 0.05$ [SAS Institute 1985]) was used to analyze the median developmental periods and percentage survivorship for each instar, the total developmental period (egg to adult), and adult weights. The Catmod procedure $(P \leq 0.05$ [SAS Institute 1985]) was used to analyze sex ratio data.

Reproductive Biology and Longevity of Squash Bugs. To determine if the dietary history of nymphal squash bugs affected adult reproductive biology and longevity, adult squash bugs were collected on the day of emergence and female-male pairs reared on the same cultivar were placed in small cylinder cages that contained an experimental plant. Cages were held in growth chambers under the experimental conditions described above. Space constraints limited the number of observations to five to six mating pairs for each replicate cage per treatment. Every other day the number of egg masses and the number of eggs per mass were counted in each cylinder cage over the lifetime of the female. Plants were watered and replaced as described above. The reproductive schedule (number of eggs per female per day and number of eggs per female per week) and male and female longevities were analyzed using the GLM-LS means test (SAS Institute 1985). Life table statistics, including a jacknife estimate of the intrinsic rate of increase (at the 5\% level), were calculated using a revised version of the computer program developed by Hulting et al. (1990).

Preimaginal Development, Survivorship, and Sex Ratio of G. pennsylvanicum. To determine if the dietary history of parasitoid larvae influenced preimaginal developmental time (egg to emerged adult), survivorship, and sex ratio of G. pennsylvanicum, day-old, mated female parasitoids were exposed individually for $8 \mathrm{~h}$ to a $<$-d-old squash bug egg mass (12 eggs attached to a small piece of index card) within a $7.4 \mathrm{cc}$ glass shell vial. Egg masses were obtained from squash bug females that had been reared on one of the three host plants ('Early Prolific Straight- 
Table 1. Survivorship, reproductive schedule, intrinsic rate of increase, and longevity of the squash bug reared on three Cucurbita cultivars over one generation at $26.2 \pm 0.5^{\circ} \mathrm{C}, 16: 8$ (L:D) $\mathrm{h}$, and $75 \% \mathrm{RH}$

\begin{tabular}{|c|c|c|c|}
\hline \multirow{2}{*}{ Parameter } & \multicolumn{3}{|c|}{ Treatment } \\
\hline & 'Early Prolific Straightneck' & 'Green Striped Cushaw' & 'Waltham Butternut' \\
\hline \% Survivorship to the adult stage $\mathrm{e}^{a}$ & $\pm 2.5 \mathrm{a}$ & $\pm 2.5 \mathrm{~b}$ & $17.0 \pm 3.3 b$ \\
\hline Fecundity & $356.7 \pm 21.7 \mathrm{a}$ & $\pm 18.8 \mathrm{a}$ & $403.2 \pm 12.2 \mathrm{~b}$ \\
\hline Preoviposition period & $5.1 \pm 0.7 a$ & $\pm 0.4 \mathrm{~b}$ & $\pm 0.5 \mathrm{~b}$ \\
\hline Oviposition period & $53.7 \pm 2.3 a$ & $\pm 2.0 \mathrm{a}$ & $\pm 2.2 \mathrm{a}$ \\
\hline$r_{\max }$ & $\begin{array}{l}0.091 \pm 0.004 a \\
{[0.083,0.100]}\end{array}$ & $\begin{array}{l}0.069 \pm 0.004 b \\
{[0.061,0.077]}\end{array}$ & $\begin{array}{l}0.053 \pm 0.004 b \\
{[0.044,0.061]}\end{array}$ \\
\hline Longevity ${ }^{b}$ & & & \\
\hline Female & $\pm 3.2 \mathrm{a}$ & $\pm 8.8 \mathrm{a}$ & $\pm 3.4 \mathbf{a}$ \\
\hline Male & $104.4 \pm 8.9 \mathrm{a}$ & $\pm 9.8 \mathrm{a}$ & $\pm 7.4 \mathrm{a}$ \\
\hline
\end{tabular}

Means $\pm S D$ (jacknife estimate $\pm S E$ [interval estimate] for $r_{\max }$ ) within rows followed by the same letter are not significantly different $\left(P>0.05\right.$, LSD test); for $r_{\max }$ test, see Hulting et al. (1990).

${ }^{a}$ For survivorship, $n=9$ for each treatment; for all adult responses, $n=$ no. of mating pairs: 'Early Prolific Straightneck', 54; 'Green Striped Cushaw', 54; 'Waltham Butternut', 51.

${ }^{b}$ Females and males are significantly different across all treatments.

neck', 'Green Striped Cushaw', or 'Waltham Butternut'). Ten such vials were set up for each host source and arranged in a completely randomized design in a growth chamber at $26.2 \pm 0.5^{\circ} \mathrm{C}$ and a photoperiod of 16:8 (L:D) h. A relative humidity of $\approx 75 \%$ was attained by placing the 30 vials in a plastic box that contained a saturated solution of $\mathrm{NaCl}$. Egg masses were inspected twice daily for parasitoid emergence and the sex of each newly emerged individual was recorded. Dissections were made of unemerged eggs to determine total numbers of parasitized eggs.

Reproductive Biology and Longevity of $G$. pennsylvanicum. To determine if the dietary history of parasitoid larvae affected adult reproductive biology or longevity, parasitoids were reared from host eggs deposited by squash bugs that had been cultured on the above three cultivars. Subsequently, 11 newly emerged female parasitoids from each host source were each kept with a male from the same host source for $24 \mathrm{~h}$ to ensure mating. Males then were removed and females were allowed to oviposit until death on $<\mathrm{l}$-d-old host eggs from the same or a different source.

Two tests were run, one comparing the parasitoid's life table responses on 'Waltham Butternut' with those on 'Early Prolific Straightneck' (standard susceptible cultivar) and the other comparing the responses between 'Green Striped Cushaw' and 'Early Prolific Straightneck'. In each test, the number of squash bug eggs provided to each female over her lifetime (range of 25 eggs on days 1-2 to seven eggs after $3 \mathrm{wk}$ ) was based on the reproductive schedule of $G$. pennsylvanicum reported by Nechols et al. (1989). Vials were placed in a growth chamber under the conditions described for the preimaginal experiment. Exposed host eggs then were removed from the vials daily and placed in tissue culture well-plates in another humidity box. The longevity of each female was recorded. For each female, we recorded the number of adult progeny that emerged, the sex, and the total developmental period (parasitization to emergence). Data were analyzed using GLM-LS means test $(P \leq 0.05$ [SAS Institute 1985]). The Catmod procedure ( $P \leq 0.05$ [SAS Institute 1985]) was used to analyze sex ratio data. Life table statistics were calculated using a modification of the computer program developed by Hulting et al. (1990), and intrinsic rates of increase $\left(\mathrm{r}_{\max }\right)$ were compared at $P \leq 0.05$.

\section{Results}

Preimaginal Development, Survivorship, Sex Ratio, and Adult Weights of Squash Bugs. The total developmental period (egg to adult) of squash bugs ranged from 31 to $35 \mathrm{~d}$ and did not differ significantly among cultivars or between generations $(P>0.05)$. Egg survivorship was $100 \%$ for all treatments. However, total survivorship (egg to adult) was significantly greater $(P<$ 0.05 ) on 'Early Prolific Straightneck' than on the other two cultivars (Table 1). Approximately $50 \%$ of the squash bugs survived to the adult stage on 'Early Prolific Straightneck' compared with $22 \%$ on 'Green Striped Cushaw' and $17 \%$ on 'Waltham Butternut'. Differences in survival occurred mainly in second and third instars (Fig. 1). Sex ratio did not differ significantly $(P>0.05)$ among cultivars or between generations; the percentage females produced ranged from 48 to 52 .

In the two-generation experiment, percentage survivorship of squash bugs to the adult stage was significantly greater $(P<0.05)$ in the first generation on 'Early Prolific Straightneck' than on 'Waltham Butternut' (Fig. 2). However, in the second generation, there was no significant difference in squash bug survivorship between the two cultivars. Furthermore, a significantly greater $(P<0.05)$ percentage of second-generation squash bugs survived to adulthood on 'Waltham Butternut' (38.5\%) than in the first generation (19.3\%). In both the first and second gen- 


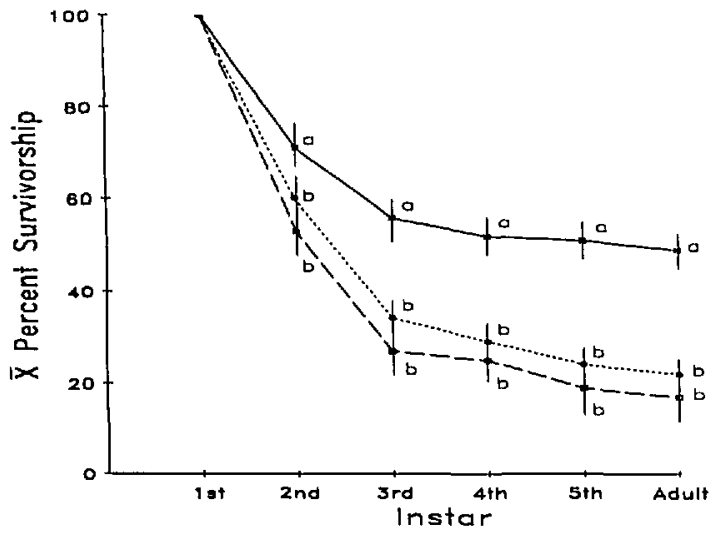

Fig. 1. Mean cumulative percentage of squash bugs surviving to each indicated instar on three Cucurbita hosts: 'Early Prolific Straightneck' squash, solid line; 'Green Striped Cushaw' pumpkin, dotted line; 'Waltham Butternut' squash, dashed line; at $26.2 \pm$ $0.5^{\circ} \mathrm{C}, 75 \% \mathrm{RH}, 16: 8$ (L:D) h photoperiod. Curves followed by a different letter are significantly different $(P<0.05$; LSD test); $\boldsymbol{n}=9$. Vertical bars denote standard deviation.

erations, survivorship was similar on 'Early Prolific Straightneck'.

Reproductive Biology and Longevity of Squash Bugs. The mean fecundity of squash bugs was significantly greater $(P<0.05)$ on 'Waltham Butternut' (403.2 eggs) than on the other two cultivars (Table 1). The preoviposition period was significantly longer $(P<0.05)$ by $\approx 21 / 2$ days on 'Green Striped Cushaw' and 'Waltham Butternut' than on 'Early Prolific Straightneck'. However, there were no significant differences among cultivars in either oviposition period or male and female longevity $(P>$ 0.05 ). Males lived $\approx 38 \%$ longer than females on all cultivars (Table 1 ).

During the first week of adult life, females laid significantly more eggs $(P<0.05)$ on 'Green Striped Cushaw' and 'Waltham Butternut' than on 'Early Prolific Straightneck' (Fig. 3). Thereafter, no significant differences were observed. Sixty-five to $75 \%$ of the eggs were laid by the end of the third week and, by the fourth week, oviposition had greatly decreased on all cultivars. In addition, squash bugs reared on 'Waltham Butternut' and 'Green Striped Cushaw' laid egg masses of a significantly larger $(P<0.05)$ size within the first week of oviposition compared with females reared on "Early Prolific Straightneck': $51.3 \pm 17.1$ ('Waltham Butternut'), $45.8 \pm$ 10.9 ('Green Striped Cushaw'), and $22.3 \pm 9.8$ ('Early Prolific Straightneck') (means \pm SD). The jacknife estimate of the intrinsic rate of increase $\left(r_{\max }\right)$ of squash bugs was significantly greater on 'Early Prolific Straightneck' $(P<0.05)$ than on the other two cultivars (Table 1).

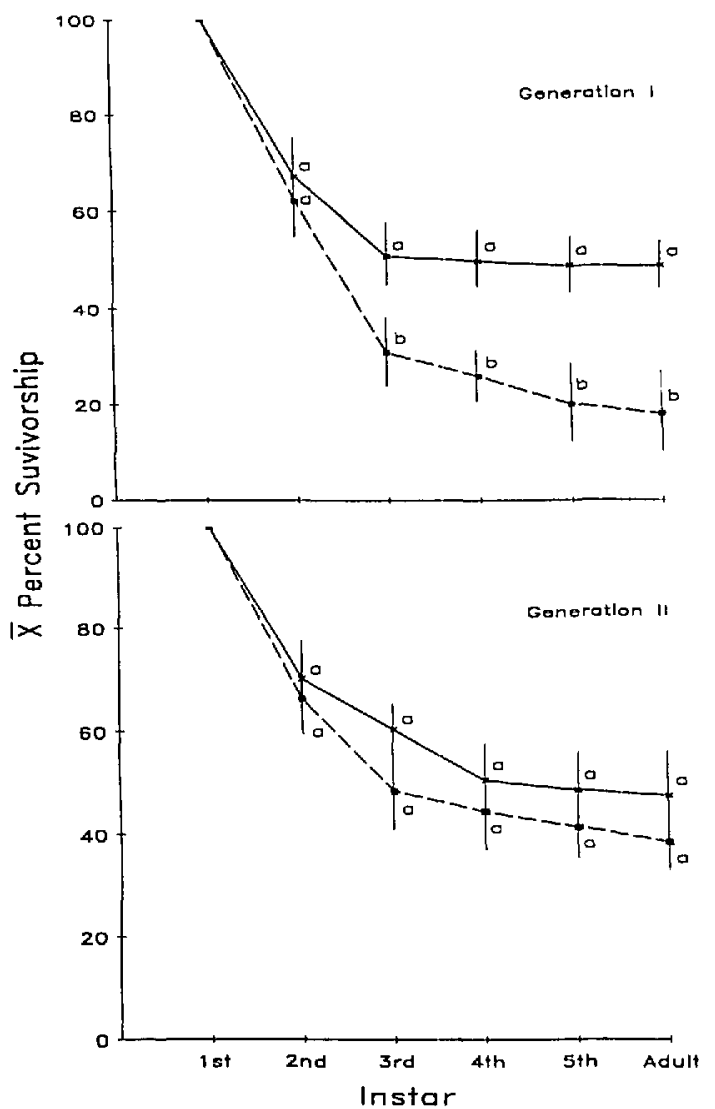

Fig. 2. Mean cumulative percentage of squash bugs surviving to each indicated instar on two Cucurbita hosts: 'Early Prolific Straightneck' squash, solid line, and 'Waltham Butternut' squash, dashed line, over two generations at $26.2 \pm 0.5^{\circ} \mathrm{C}, 75 \% \mathrm{RH}, 16: 8$ (L:D) h photoperiod. Curves followed by a different letter are significantly different $(P<0.05$, LSD test); $n=4$. Vertical bars denote standard deviation.

In the two-generation study, fecundities were similar between generations and between cultivars (Table 2). In both generations, the preoviposition periods were significantly $(P<0.05)$ shorter on 'Early Prolific Straightneck' than on 'Waltham Butternut'. In the first generation, $r_{\max }$ was significantly greater on 'Early Prolific Straightneck' than on 'Waltham Butternut'; however, these values did not differ between cultivars in the second generation.

Preimaginal Development, Survivorship, and Sex Ratio of G. pennsylvanicum. Preimaginal development, survivorship, and sex ratio of this parasitoid were not significantly affected by its larval diet (Table 3). In all treatments, developmental time was $\approx 17 \mathrm{~d}$, survivorship ranged from 88 to $91 \%$, and the proportion of females produced was $\approx 83 \%$.

Reproductive Biology and Longevity of $G$. pennsylvanicum. The oviposition period and fecundity did not differ significantly $(P>0.05)$ 


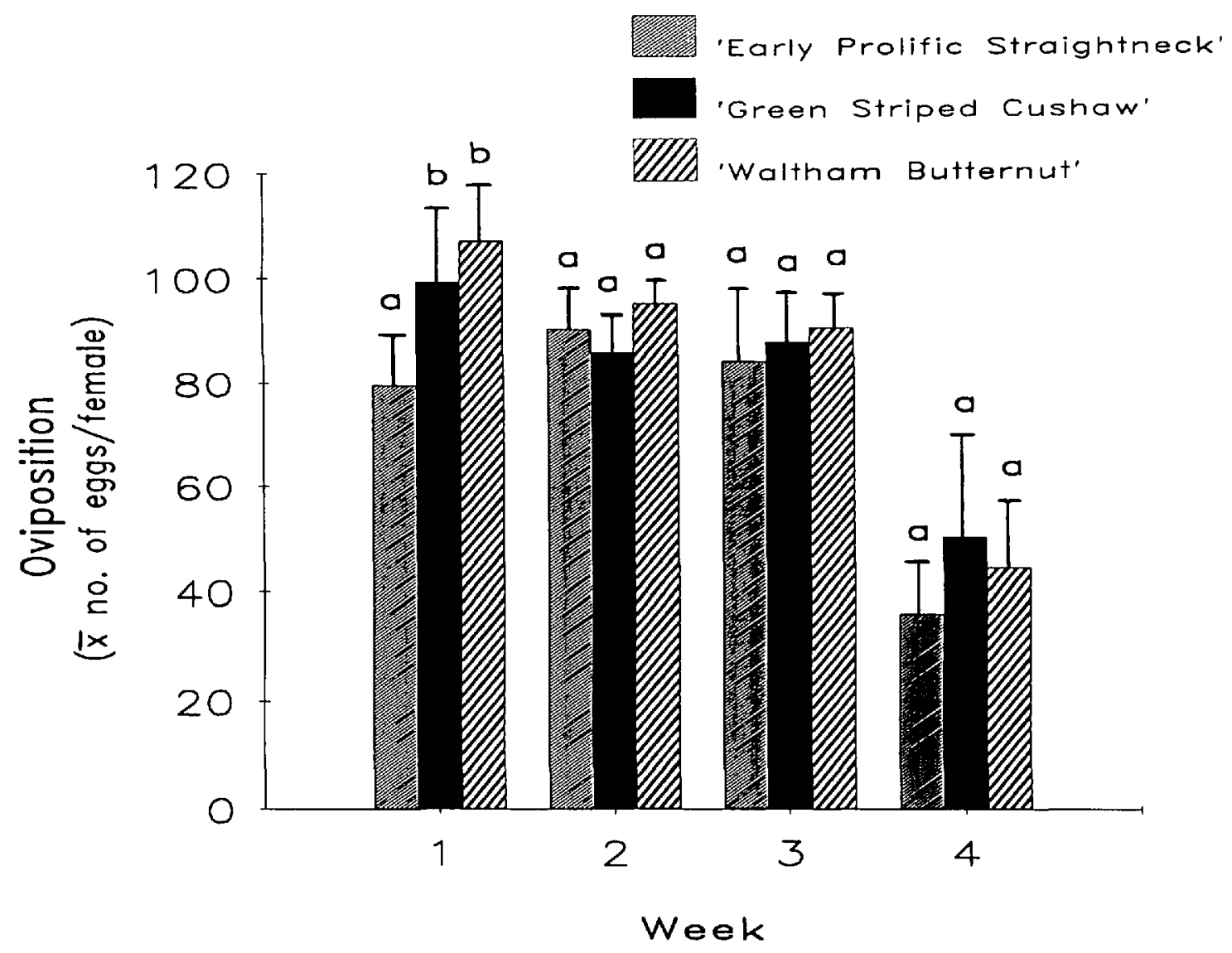

Fig. 3. Weekly oviposition schedule of the squash bug on three Cucurbita hosts: 'Early Prolific Straightneck' squash, 'Green Striped Cushaw' pumpkin, and 'Waltham Butternut' squash, at $26.2 \pm 0.5^{\circ} \mathrm{C}, 75 \%$ RH, 16:8 (L:D) $\mathrm{h}$ photoperiod. Data for $2 \mathrm{~d}$ oviposition pooled over each week. Statistical comparisons among cultivars are within week; bars under a different letter are significantly different $(P<0.05$; LSD test). No. of mating pairs: 'Early Prolific Straightneck', 54, 'Green Striped Cushaw', 54, 'Waltham Butternut', 51.

among treatments (Table 4). However, adult longevity was significantly $(P<0.05)$ shorter in $G$. pennsylvanicum females from eggs of squash bugs that had been reared on "Waltham Butternut' than from those reared on 'Early Prolific Straightneck'. The cultivar on which adult parasitoids oviposited had no effect on their longevity or intrinsic rate of increase $(P>0.05)$ (Table 4).

\section{Discussion}

Squash bug survivorship on 'Waltham Butternut' and 'Green Striped Cushaw' was significantly lower than that observed on the standard cultivar 'Early Prolific Straightneck'. These differences in survivorship are directly related to high mortality in second and third instars and may represent the effect of antibiosis (Painter 1951, Novero et al. 1962). However, the specific mechanism(s) of resistance contributing to reduced squash bug survival on these two cultivars are presently not known. Either antibiosis or nonpreference (antixenosis), or some combination of the two, could be involved. Allelochemicals could affect early instar survival. Alternatively, nymphs may receive insufficient nutrients from these cultivars, either because they do not feed enough or because the diet is qualitatively deficient. Survivors presumably exhibit lower levels of nonpreference or else are more tolerant of the plant's antibiotic properties.

The preovipositional period of the squash bugs was longer by about $2 \mathrm{~d}$ on both resistant cultivars ('Green Striped Cushaw' and 'Waltham Butternut') than on the more susceptible 'Early Prolific Straightneck'. Initial egg masses throughout the first week also were larger on these two cultivars than on the 'Early Prolific Straightneck' cultivar. These findings may indicate an ovipositional nonpreference that results in the accumulation of mature eggs in the squash bug's reproductive tract. However, because survivorship to the adult stage was very low on 'Green Striped Cushaw' and 'Waltham Butternut', the slight differences we observed in fecun- 
Table 2. Survivorship, reproductive schedule, intrinsic rate of increase, and longevity of the squash bug reared on two Cucurbita cultivars over two consecutive generations at $26.2 \pm 0.5^{\circ} \mathrm{C}, 16: 8$ (L:D) h, and RH $75 \%$

\begin{tabular}{|c|c|c|c|c|c|c|c|c|}
\hline \multirow{3}{*}{ Parameter } & \multicolumn{8}{|c|}{ Treatment } \\
\hline & \multicolumn{4}{|c|}{ Generation 1} & \multicolumn{4}{|c|}{ Generation 2} \\
\hline & \multicolumn{2}{|c|}{$\begin{array}{l}\text { 'Early Prolific } \\
\text { Straightneck' }\end{array}$} & \multicolumn{2}{|c|}{$\begin{array}{l}\text { 'Waltham } \\
\text { Butternut' }\end{array}$} & \multicolumn{2}{|c|}{$\begin{array}{l}\text { 'Early Prolific } \\
\text { Straightneck' }\end{array}$} & \multicolumn{2}{|c|}{$\begin{array}{l}\text { 'Waltham } \\
\text { Butternut' }\end{array}$} \\
\hline \% Survivorship to the adult stage ${ }^{a}$ & 49.5 & $\pm 1.3 \mathrm{a}$ & 19.3 & $\pm 2.1 \mathrm{~b}$ & 50.6 & $\pm 3.2 \mathrm{a}$ & 38.5 & $\pm 9.2 \mathrm{a}$ \\
\hline Fecundity & 379.9 & $\pm 12.4 \mathrm{a}$ & 382.5 & $\pm 22.3 \mathrm{a}$ & 351.9 & $\pm 23.0 \mathrm{a}$ & 391.1 & $\pm 20.5 \mathrm{a}$ \\
\hline Preoviposition period & 4.9 & $\pm 0.9 \mathrm{a}$ & 7.1 & $\pm 0.6 \mathrm{~b}$ & 5.5 & $\pm 0.8 \mathrm{a}$ & 6.9 & $\pm 0.6 \mathrm{~b}$ \\
\hline Oviposition period & 55.1 & $\pm 6.2 \mathrm{a}$ & 54.2 & $\pm 4.8 \mathrm{a}$ & 53.2 & $\pm 4.0 \mathrm{a}$ & 51.0 & $\pm 2.9 \mathrm{a}$ \\
\hline$r_{\max }$ & $\begin{array}{l}0.087 \\
{[0.07}\end{array}$ & $\begin{array}{l} \pm 0.008 \mathrm{a} \\
1,0.103]\end{array}$ & $\begin{array}{l}0.067 \\
{[0.05}\end{array}$ & $\begin{array}{l} \pm 0.007 \mathrm{~b} \\
1,0.082]\end{array}$ & $\begin{array}{l}0.085 \\
{[0.07}\end{array}$ & $\begin{array}{l} \pm 0.008 \mathrm{a} \\
0,0.101]\end{array}$ & $\begin{array}{l}0.08 \\
{[0.06}\end{array}$ & $\begin{array}{l} \pm 0.008 \mathrm{a} \\
6,0.097]\end{array}$ \\
\hline \multicolumn{9}{|l|}{ Longevity ${ }^{b}$} \\
\hline Female & 62.3 & $\pm 6.8 \mathrm{a}$ & 70.1 & $\pm 10.0 \mathrm{a}$ & 65.9 & $\pm 7.4 \mathrm{a}$ & 68.3 & $\pm 8.1 \mathrm{a}$ \\
\hline Male & 101.4 & $\pm 11.5 \mathrm{a}$ & 107.0 & $\pm 11.8 \mathrm{a}$ & 99.5 & $\pm 9.0 \mathrm{a}$ & 108.4 & $\pm 7.5 \mathrm{a}$ \\
\hline \multicolumn{9}{|l|}{ Teneral weight (mg) } \\
\hline Female & 177.5 & $\pm 18.4 a$ & 201.1 & $\pm 7.8 \mathrm{a}$ & 165.0 & $\pm 10.5 \mathrm{a}$ & 195.0 & $\pm 11.3 \mathrm{a}$ \\
\hline Male & 113.7 & $\pm 9.8 \mathrm{a}$ & 129.3 & $\pm 6.6 \mathrm{a}$ & 118.9 & $\pm 6.8 \mathrm{a}$ & 126.2 & $\pm 7.8 \mathrm{a}$ \\
\hline
\end{tabular}

Means $\pm S D$ (jacknife estimate \pm SE [interval estimate] for $r_{\text {max }}$ ) within rows followed by the same letter are not significantly different $\left(P>0.05, \mathrm{LSD}\right.$ test); for $\mathrm{r}_{\max }$ test, see Hulting et al. (1990).

a For survivorship, $n=9$; for adult responses, $n=$ no. of mating pairs: generation 1, 'Early Prolific Straightneck', 24; 'Waltham Butternut', 22; generation 2, 'Early Prolific Straightneck', 24; 'Waltham Butternut', 24.

${ }^{b}$ Females and males are significantly different for both longevity and teneral weight across all treatments.

dity probably would not have an important impact on squash bug population dynamics under field conditions. In fact, reduced survivorship seemed to effectively counteract any increase in fecundity because the intrinsic rates of increase were lower on both resistant cultivars than on 'Early Prolific Straightneck'. Furthermore, a significantly higher fecundity occurred in only one of the two tests (the single-generation study) on 'Waltham Butternut', with the greater numbers of squash bug eggs being laid in the first week of oviposition. This may represent experimental variation rather than a biologically significant difference in the general population.

Increased squash bug survivorship on 'Waltham Butternut' occurred within two generations in the laboratory. This may be a result of physiological or behavioral adaptation. Or it may represent selection for more tolerant genotypes. The latter may be a less likely explanation because

Table 3. Preimaginal development, survivorship, and sex ratio of G. pennsylvanicum from host eggs of the squash bug reared on three Cucurbita cultivars at $26.2 \pm$ $0.5^{\circ} \mathrm{C}, 16: 8$ (L:D) h, and $75 \% \mathrm{RH}$

\begin{tabular}{|c|c|c|c|}
\hline Treatment $t^{a}$ & 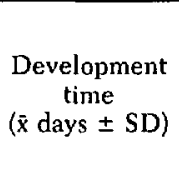 & $\begin{array}{c}\% \\
\text { Survivorship } \\
\text { (total no. } \\
\text { emerged/ } \\
\text { total } \\
\text { parasitized) }\end{array}$ & $\begin{array}{c}\% \text { Females } \\
\text { (no. females/ } \\
\text { total } \\
\text { emerged) }\end{array}$ \\
\hline $\begin{array}{l}\text { 'Early Prolific } \\
\text { Straightneck' }\end{array}$ & $17.4 \pm 0.72$ & $91.3(63 / 69)$ & $84.1(53 / 63)$ \\
\hline $\begin{array}{l}\text { 'Green Striped } \\
\text { Cushaw' }\end{array}$ & $17.6 \pm 0.52$ & $90.6(68 / 75)$ & $83.8(57 / 68)$ \\
\hline $\begin{array}{l}\text { 'Waltham } \\
\text { Butternut' }\end{array}$ & $17.6 \pm 0.69$ & $88.2(75 / 85)$ & $82.6(62 / 75)$ \\
\hline
\end{tabular}

${ }^{a}$ No significant differences $(P>0.05$; LSD test). No. of females $=10$ for all treatments. our study involved only two generations. However, this possibility should be assessed experimentally. Regardless of the underlying cause, 'Waltham Butternut'-a late-season squashwould not typically be planted in a double-cropping sequence. Therefore, even though field populations of squash bugs may undergo two generations in Kansas (Nechols 1987), exposure to consecutive plantings of this resistant cultivar would not likely occur.

The host plant on which squash bugs were reared had no influence on any aspect of $G$. pennsylvanicum's preimaginal or adult biology except for longevity. Adult longevity was reduced significantly in parasitoids that emerged from eggs from squash bugs reared on the most resistant cultivar, 'Waltham Butternut'. 'Green Striped Cushaw' pumpkins, which also were resistant to squash bugs, had no effect on the lifespan of the egg parasitoid. Because adult parasitoids were supplied with egg masses that had been isolated from intact host plants, it appears that differences in longevity are related to the dietary history of developing egg parasitoids. Differences in longevity may derive from qualitative or quantitative nutritional differences within host eggs, differences in secondary chemicals, or some combination of these. If antibiosis to the squash bug exists, toxins may accumulate-or dietary deficiencies may exist-in the more tolerant surviving bugs that could be passed on in their eggs. If, because of antixenosis, squash bug feeding is reduced, squash bug eggs also may lack sufficient nutrients for $G$. pennsylvanicum. Either mechanism could eventually contribute to reduced longevity of $G$. pennsylvanicum emerging from squash bug eggs associated with 'Waltham Butternut'. 
Table 4. Oviposition period, fecundity, intrinsic rate of increase, and longevity of $G$. pennsylvanicum from squash bug eggs from three Cucurbita cultivars at $26.2 \pm 0.5^{\circ} \mathrm{C}, 16: 8$ (L:D) h, and $75 \% \mathrm{RH}$

\begin{tabular}{|c|c|c|c|c|}
\hline Cultivar & Oviposition period & Fecundity & $r_{\max }$ & Longevity \\
\hline $\begin{array}{l}\text { Experiment } 1 \\
\text { 'Early Prolific Straightneck' } \rightarrow \\
\text { 'Early Prolific Straightneck' }\end{array}$ & $24.4 \pm 9.4 a$ & $70.5 \pm 28.0 \mathrm{a}$ & $\begin{array}{c}0.180 \pm 0.004 \mathrm{a} \\
{[0.170,0.190]}\end{array}$ & $41.5 \pm 17.2 \mathrm{a}$ \\
\hline $\begin{array}{l}\text { 'Early Prolific Straightneck' } \rightarrow \\
\text { 'Waltham Butternut' }\end{array}$ & $25.5 \pm 9.1 \mathrm{a}$ & $65.1 \pm 22.5 \mathrm{a}$ & $\begin{array}{c}0.177 \pm 0.005 \mathrm{a} \\
{[0.167,0.188]}\end{array}$ & $40.4 \pm 17.6 \mathrm{a}$ \\
\hline $\begin{array}{l}\text { 'Waltham Butternut' } \rightarrow \\
\text { 'Early Prolific Straightneck' }\end{array}$ & $21.4 \pm 7.9 \mathrm{a}$ & $62.4 \pm 17.9 \mathrm{a}$ & $\begin{array}{c}0.179 \pm 0.004 \mathrm{a} \\
{[0.170,0.188]}\end{array}$ & $28.5 \pm 9.4 b$ \\
\hline $\begin{array}{l}\text { 'Waltham Butternut' } \rightarrow \\
\text { 'Waltham Butternut' }\end{array}$ & $19.7 \pm 10.2 \mathrm{a}$ & $67.9 \pm 24.4 \mathrm{a}$ & $\begin{array}{c}0.183 \pm 0.005 \mathrm{a} \\
{[0.173,0.194]}\end{array}$ & $27.3 \pm 13.9 \mathrm{~b}$ \\
\hline $\begin{array}{l}\text { Experiment } 2 \\
\text { 'Early Prolific Straightneck' } \rightarrow \\
\text { 'Early Prolific Straightneck' }\end{array}$ & $25.7 \pm 8.9 a$ & $63.4 \pm 19.8 \mathrm{a}$ & $\begin{array}{c}0.179 \pm 0.003 a \\
{[0.171,0.186]}\end{array}$ & $39.2 \pm 16.3 \mathrm{a}$ \\
\hline $\begin{array}{l}\text { 'Early Prolific Straightneck' } \rightarrow \\
\text { 'Green Striped Cushaw' }\end{array}$ & $24.3 \pm 8.2 \mathrm{a}$ & $64.8 \pm 20.1 \mathrm{a}$ & $\begin{array}{c}0.179 \pm 0.003 a \\
{[0.172,0.185]}\end{array}$ & $37.7 \pm 16.2 \mathrm{a}$ \\
\hline $\begin{array}{l}\text { 'Green Striped Cushaw' } \rightarrow \\
\text { 'Early Prolific Straightneck' }\end{array}$ & $23.6 \pm 7.5 \mathrm{a}$ & $70.8 \pm 24.3 a$ & $\begin{array}{c}0.185 \pm 0.004 a \\
{[0.177,0.194]}\end{array}$ & $38.3 \pm 16.5 \mathrm{a}$ \\
\hline $\begin{array}{l}\text { 'Green Striped Cushaw' } \rightarrow \\
\text { 'Green Striped Cushaw' }\end{array}$ & $21.9 \pm 8.0 \mathrm{a}$ & $69.4 \pm 25.7 \mathrm{a}$ & $\begin{array}{c}0.184 \pm 0.004 \mathrm{a} \\
{[0.174,0.193]}\end{array}$ & $36.9 \pm 15.3 \mathrm{a}$ \\
\hline
\end{tabular}

Means $\pm S D$ (jacknife estimate \pm SE [interval estimate] for $r_{\text {max }}$ ) within a column followed by the same letter are not significantly different $(P>0.05$, LSD test $)$; no $r_{\max }$ estimates were significantly different $(P>0.05)$; for $r_{\text {max }}$ test, see Hulting et al. (1990). Cultivar preceding arrow, eggs in which parasitoids develop; cultivar following arrow, eggs on which parasitoids oviposit; no. of females $=11$ for all cultivars.

Differences in longevity notwithstanding, it appears that the use of resistant cultivars would not decrease the fitness of G. pennsylvanicum because, in all cases, parasitoids in the laboratory had completed oviposition before dying. This conclusion is also supported by the similar $r_{\max }$ values. On the other hand, parasitoids in the field may not encounter the continuous supply of host eggs that were available in our laboratory experiments. Thus, host deprivation may cause a shift in the oviposition schedule, and reduced longevity could then be important if females died before depositing their full complement of eggs (see Flanders 1942). Our unpublished data, however, suggest that this does not occur in G. pennsylvanicum.

A comparison of $r_{\max }$ values between the squash bug and $G$. pennsylvanicum indicates that the parasitoid is capable of increasing its populations about twice as fast as its host can. This is likely due to G. pennsylvanicum's shorter preimaginal development time (less than half that of the squash bug) and its relatively greater survivorship.

Our findings are similar to those of Ruberson et al. (1989), who found that Edovum puttleri Grissell, a eulophid egg parasitoid of the Colorado potato beetle, had reduced longevity when reared from host eggs associated with resistant potatoes. Our results differ from those of Orr et al. (1985), who showed that survivorship to adulthood in the scelionid egg parasitoid Telenomus chloropus Ashmead was significantly lower in southern green stink bug eggs from resistant soybeans than in eggs from bugs reared on suscep- tible soybeans. These findings reveal that indirect effects of host plants on egg parasitoids are variable, thus underscoring the need for conducting studies to assess trophic level effects on different species and in different agroecosystems.

Resistant cultivars do not appear to adversely affect the biology of $G$. pennsylvanicum within the host egg. Thus, it may be possible to use biological control compatibly with host plant resistance in an integrated pest management program for the squash bug. However, because host plant species and resistance have been shown to have a negative impact on foraging by natural enemies, including another Gryon species (Morrill \& Almazon 1990), possible effects of resistant plants on the foraging efficiency of G. pennsylvanicum should be examined.

\section{Acknowledgments}

We thank K. Kemp (Kansas State University) for statistical assistance and D. Orr (Iowa State University), R. Collins, and L. J. Krchma (Kansas State University) for computer assistance. We are grateful to F. Hulting (Alcoa Technical Center, Alcoa Center, PA) for providing a revised version of the computer program for calculating $r_{\max }$ values. We also thank $D$. Margolies (Kansas State University) for reviewing the manuscript. This is contribution No. 92-578-J from the Kansas Agricultural Experiment Station.

\section{References Cited}

Benepal, P. S. \& C. V. Hall. 1967. Biochemical studies of plants of Cucurbita pepo L. varieties as re- 
lated to feeding response of squash bug Anasa tristisDe Geer. Proc. Am. Soc. Hortic. Sci. 91: 361-365.

Bergman, J. M. \& W. M. Tingey. 1979. Aspects of interaction between plant genotypes and biological control. Bull. Entomol. Soc. Am. 25: 275-279.

Boethel, D. J. \& R. D. Eikenbary. [eds.] 1986. actions of plant resistance and parasitoids and predators of insects. Wiley, New York.

Campbell, B. C. \& S. S. Duffey. 1979. Tomatine and parasitic wasps: potential incompatibility of plantantibiosis with biological control. Science (Washington, DC) 205: 700-702.

Flanders, S. E. 1942. Oosorption and ovulation in relation to oviposition in the parasitic Hymenoptera. Ann. Entomol. Soc. Am. 35: 251-266.

Hulting, F. L., D. B. Orr \& J. J. Obrycki. 1990. A computer program for calculation and statistical comparison of intrinsic rates of increase and associated life table parameters. Fla. Entomol. 73: 601612.

Kauffman, W. C. \& G. G. Kennedy 1989a. Inhibition of Campoletis sonorensis parasitism of $\mathrm{He}$ liothis zea and of parasitoid development by 2 tridecanone-mediated insect resistance of wild tomato. J. Chem. Ecol. 15: 1919-1930.

1989b. Toxicity of allelochemicals from wild insectresistant tomato Lycopersicon hirsutum $f$. glabratum to Campoletis sonorensis, a parasitoid of $\mathrm{He}$ liothis zea. J. Chem. Ecol. 15: 2051-2060.

Morrill, W. L. \& L. P. Almazon. 1990. Effect of host plant species and age of rice bug (Hemiptera: Alydidae) eggs on parasitism by Gryon nixoni (Hymenoptera: Scelionidae). J. Entomol. Sci. 25: 450452 .

Nechols, J. R. 1985. The squash bug: biology and management. Coop. Ext. Serv. Bull. 505. Coop. Ext. Serv., Kansas State University, Manhattan, KS.

1987. Voltinism, seasonal reproduction, and diapause in the squash bug (Heteroptera: Coreidae) in Kansas. Environ. Entomol. 16: 269-273.

Nechols, J. R., J. L. Tracy \& E. A. Vogt. 1989. Comparative ecological studies of indigenous egg parasitoids (Hymenoptera: Scelionidae: Encyrtidae) of the squash bug, Anasa tristis (Hemiptera: Coreidae). J. Kans. Entomol. Soc. 62: 177-188.
Novero, S., R. H. Painter \& C. V. Hall. 1962. Interrelations of the squash bug, Anasa tristis, and six varieties of squash (Cucurbita spp.). J. Econ. Entomol. 55: 912-919.

Obrycki, J. J. 1986. The influence of foliar pubescence on entomophagous species, pp. 61-83. In

- D. J. Boethel \& R. D. Eikenbary [eds.], Interactions of plant resistance and parasitoids and predators of insects. Wiley, New York.

Orr, D. B., D. J. Boethel \& W. A. Jones. 1985. Biology of Telenomus chloropus (Hymenoptera: Sceionidae) from eggs of Nezera viridula (Hemiptera: Pentatomidae) reared on resistant and susceptible soybean genotypes. Can. Entomol. 117: 1137-1142.

Painter, R. H. 1951. Insect resistance in crop plants MacMillan, New York.

Price, P. W., C. E. Bouton, P. Gross, B. A. McPheron, J. N. Thompson \& A. E. Weis. 1980 . Interactions among three trophic levels: influence of plants on interactions between insect herbivores and natura enemies. Annu. Rev. Ecol. Sys. 11: 41-65.

Ruberson, J. R., M. J. Tauber, C. A. Tauber \& W. M. Tingey. 1989. Interactions at three trophic levels: Edovum puttleri Grissell (Hymenoptera: Eulophidae), the Colorado potato beetle, and insectresistant potatoes. Can. Entomol. 121: 841-851.

SAS Institute. 1985. SAS user's guide: statistics. SAS Institute, Cary, NC.

Thurston, R. \& P. M. Fox. 1972. Inhibition by nicotine of emergence of Apanteles congregatus from its host the tobacco hornworm. Ann. Entomol. Soc Am. 65: 547-550.

Tracy, J. L. \& J. R. Nechols. 1987. Comparisons between the squash bug egg parasitoids Ooencyrtus anasae and $O$. sp. (Hymenoptera: Encyrtidae): development, survival, and sex ratio in relation to temperature. Environ. Entomol. 16: 1324-1329.

1988. Comparison of thermal responses, reproductive biologies, and population growth potentials of the squash bug egg parasitoids Ooencurtus anasae and $O$. sp. (Hymenoptera: Encyrtidae). Environ Entomol. 17: 636-643

Received for publication 18 May 1992; accepted 25 September 1992. 